NBER WORKING PAPER SERIES

\title{
THE EFFICIENCY OF SELF-REGULATED \\ PAYMENTS SYSTEMS: LEARNING \\ FROM THE SUFFOLK SYSTEM
}

\author{
Charles W. Calomiris \\ Charles M. Kahn
}

Working Paper 5442
NATIONAL BUREAU OF ECONOMIC RESEARCH 1050 Massachusetts Avenue
Cambridge, MA 02138
January 1996

This paper was prepared for the Conference on Payment Systems Research and Public Policy, sponsored by the Board of Governors of the Federal Reserve System and the Journal of Money, Credit, and Banking. The authors thank Daniel Arce, Allen Berger, Heesoo Chung, Diana Hancock, Flavio Menezes, George Williams, participants in the Conference on Payment System Research and participants in the 30th Annual Cliometrics Conference. Financial support from the Herbert V. Prochnow Foundation of the Graduate School of Banking, Madison, Wisconsin, is gratefully acknowledged. This paper is part of NBER's research program in the Development of the American Economy. Any opinions expressed are those of the authors and not those of the National Bureau of Economic Research.

() 1996 by Charles W. Calomiris and Charles M. Kahn. All rights reserved. Short sections of text, not to exceed two paragraphs, may be quoted without explicit permission provided that full credit, including () notice, is given to the source. 


\title{
THE EFFICIENCY OF SELF-REGULATED \\ PAYMENTS SYSTEMS: LEARNING \\ FROM THE SUFFOLK SYSTEM
}

\begin{abstract}
This paper analyzes the operation of the Suffolk System, an interbank note-clearing network operating throughout New England from the 1820s through the 1850s. Banks made markets in each other's notes at par, which allowed New England to avoid the discounting of bank notes in trade. Privately enforced regulations prevented free riding in the form of excessive risk taking. Observers of the Suffolk System have been divided. Some emphasized the stability and efficiency of these arrangements. Others argued that the arrangements were motivated by rent-seeking on the part of Boston banks, and were primarily coercive and exploitative.

In the neighboring Mid-Atlantic states, regulations limited the potential for developing a regional clearing system centered in New York City on the model of the Suffolk System. This difference makes it possible to compare the performance of banks across regulatory regimes to judge the relative merits of the sanguine and jaundiced views of the Suffolk System.

Evidence supports the sanguine view. New England's banks were able to issue more notes and these notes traded at uniform and low discount rates compared to those of other banks. An examination of the balance sheets and stock returns of Boston and New York City banks indicates that the stock market perceived that bank lending produced less risk for bank debt holders in Boston than in New York. The benefits of the system extended outside of Boston. Peripheral New England banks displayed high propensities to issue notes, and were able to maintain low specie reserves. Boston banks did not exhibit high profit rates or high ratios of market-to-book values of equity; thus there is no evidence that Boston banks extracted rents from their control of the payments system.
\end{abstract}

Charles W. Calomiris Department of Finance University of Illinois at Urbana-Champaign 340 Commerce West Champaign, IL 61820 and NBER
Charles M. Kahn Department of Economics University of Illinois at Urbana-Champaign 330 Commerce West Champaign, IL 61820 


\section{Introduction}

For much of the twentieth century, cooperative arrangements among banks have been peripheral to bank regulation. Since the establishment of the Federal Reserve System and the FDIC, most of the rules under which banks operate and transact with one another are controlled by government agencies. Recently, this has been changing. The CHIPS network operates as a private, self-regulating interbank clearing house across national boundaries. Also, prospective non-bank entrants into the domestic payments system (operating through stored value cards or nonbank electronic clearing networks) are raising the possibility of a significant parallel payment clearing system outside the control of banks or federal banking regulators.

In considering these new developments, economists and regulators have raised concerns about payment-system "externalities" and about potential anti-competitive implications of powerful private payments networks. Do private clearing systems adequately protect themselves from externalities? Do private clearing systems promote anti-competitive behavior by providing a means for large banks to restrict entry or to control competitors? Are there defensible arguments for public control of the payments system as a means to ensure stability and competition?

With respect to stability, the record thus far of CHIPS, and other private clearing houses, has been good. Of course, this record only spans a short period of time, and may not be an adequate indicator of future vulnerability. Historical insights can be useful for evaluating the efficiency of private payment systems and bank self regulation. At various times in the nineteenth and twentieth centuries American banks coordinated their activities through voluntary cooperative arrangements, which often functioned as the primary avenue for regulation. These arrangements took many forms, among them clearing houses in the banking centers and correspondent relationships between money-center banks and banks in other locales. These organizations took on tasks that are now regarded as the natural preserve of federal regulators and institutions. Some 
provided self-imposed regulations on reserve holdings, portfolio composition, or the creation of bank liabilities; some required members to accept each other's liabilities on prespecified terms; some also provided co-insurance of member banks during crises.

In this paper, we analyze the operation of the Suffolk System, an important early example of a self-regulating bank clearing system. The Suffolk System was an interbank note-clearing network operating throughout New England from the 1820s through the 1850 s, and was the precursor to other forms of interbank cooperation in the payments system. Banks throughout New England made markets in each other's notes at par, which allowed New England to avoid the discounting of bank notes in trade. Outside of New England, New England banks' notes traded at small discounts and at a common discount vis a vis one another. Even in the wake of financial shocks that gripped the economy over this period (including severe, nationwide banking crises in 1837, 1839, and 1857), the Suffolk System -- unlike other states' systems -- experienced minor losses on note clearings

Despite these apparent benefits, nineteenth century observers of cooperative, selfregulating banking, and of the Suffolk System in particular, were divided in their views of the desirability of self-regulating payments systems. Some took what we will call the "sanguine" view, emphasizing the stability and efficiency of these arrangements. Others took a "jaundiced" view, arguing that the arrangements to organize the payments system were motivated by rent-seeking on the part of large urban banks, and were primarily coercive and exploitative.

The division in public opinion was reflected in different government policies toward interbank cooperation in note clearing arrangements during the early nineteenth century, in the period before the national banking system monopolized bank note issuance. In New England, the Suffolk System was permitted to function unhindered by state government intervention; but in New York, the state government placed strict limits on interbank discipline and interbank note clearing, 
in an attempt to limit anti-competitive behavior. Those regulations limited the potential for developing a regional clearing system for Mid-Atlantic states centered in New York City on the model of the Suffolk System. This difference between New England and the Mid-Atlantic states make it possible for us to compare the performance of banks across regulatory regimes to judge the relative merits of the sanguine and jaundiced views of the Suffolk System. Specifically, we compare the performance of the New England states, under the Suffolk System, with that of the Mid-Atlantic states. Claims about the costs or benefits of the Suffolk System are evaluated against the "benchmark" of the Mid-Atlantic experience.

Our paper is organized as follows. Section II provides a review of several early examples of interbank relationships and their demise. That discussion describes the motivations behind successive state and federal attempts to limit or control interbank relationships in the payments system. Section III discusses the development and operation of the Suffolk System in detail, and the arguments of its proponents and detractors. Section IV describes how one can use historical evidence to distinguish between the sanguine and jaundiced views of the Suffolk System. Section V reviews data sources for the empirical results described in section VI. Section VII concludes.

\section{II.Interbank Cooperation and the Payments System in U.S. History}

In this section we briefly survey the changing forms of interbank cooperation in U.S. financial history. We also review two political banking reform movements that attempted to reduce control by private banks over the banking system. The movements we examine are the Jacksonian movement, which culminated in the nationalization of bank note issue under the national banking system, and the political movements which underlay the creation of the Federal Reserve System. In each case, privately-organized interbank relationships proved more resilient than reformers anticipated. 


\section{Early Bank Coordination}

Prior to the National Banking System, bank notes were the liabilities of the banks that issued them and were actively traded on a national market. Bank notes traded at a discount, which increased with the perceived default risk of the bank and the distance from the point of issue (see Calomiris and Schweikart, 1988, 1991, and Gorton, 1989a). Banks typically served as note brokers, clearing notes at discounts, and transferring notes inter-regionally

Beginning in the early nineteenth century, banks established agreements with banks in other locations to "make markets" in their notes. Sometimes these agreements were creations of banks, sometimes they were initiated by governments. In Massachusetts, the Boston-based Suffolk System was a privately organized network for currency redemption. Boston banks made markets in participating New England country banks' notes at a given rate of exchange, subject to overdraft limits, requirements that country banks maintain deposits at a Boston bank, and other provisions

In contrast, New York's Redemption System was a system of interbank note clearing established by that state's legislature to reduce the discount in New York City on New York country bank notes. The law set maximum discounts in New York City and required country banks to hire a New York City correspondent bank (and deposit therein whatever funds were necessary) to maintain convertibility at that rate. Unlike the Suffolk System, New York's Redemption System limited the potential for city banks to buy and sell country bank notes. City banks were only allowed to deal in the notes of their correspondents, and were not free to demand unlimited redemption of correspondents' notes without prior notice. ${ }^{1}$

In Indiana, Ohio, and Iowa, banks participated in legally mandated but privately operated coinsurance arrangements, which included interbank loan agreements, maintenance of par convertibility, and unlimited mutual liability for each other's losses. These systems enacted rules that limited leverage, banking practices, and members' portfolio risks, and the group had broad legal powers to enforce its rules, including dividend suspension and bank closure. These banking coalitions were particularly useful in averting disaster during nationwide financial crises (see Calomiris, 1989, 1990) 
In the antebellum South, state systems dominated by small groups of branching banks replicated, through informal arrangements, many of the features of the successful note-clearing and coinsurance systems of the North (Calomiris and Schweikart, 1988). The small number and geographical overlap of banks facilitated enforcement of rules for note and check clearing, as did the credible threats of large branching banks to exclude offenders from the coalition.

Arrangements for interbank note clearing were not universally popular during the antebellum period. The Second Bank of the United States, which operated branches throughout the country, had been an important note broker, and it was partly in response to its note-clearing activities that the Jacksonians opposed its re-chartering (see Temin, 1969). The Jacksonians viewed the discounting of notes as usurious of the public, and saw the transferring of notes back to their bank's home office as an attempt to monopolize banking. These complaints led the Jacksonians to advocate the separation of bank lending from note issuing, and to propose a government-controlled bank to issue notes (see Duncombe, 1841 and Schweikart, 1988). The National Banking System achieved the Jacksonian objective by effectively substituting national currency -- licensed, manufactured, and guaranteed by the federal government -- for private banks' notes

The abolition of private notes did not abolish interbank relationships. Following the enactment of national banking, checking accounts became the principal liabilities of banks. Privately organized clearing houses developed in all major American cities beginning in the $1850 \mathrm{~s}$.

At first, clearing houses primarily concemed themselves with developing means to clear checks efficiently, but later they leamed the efficacy of coordinating their behavior and engaging in mutual insurance in response to financial disturbances (see Cannon, 1910, Gorton, 1985, Gorton and Mullineaux, 1987, and Calomiris and Gorton, 1991), in much the same way as the earlier mutual liability systems of Indiana, Ohio, and Iowa.

While it would have been useful to expand the geographical range of clearing houses to the regional or national level -- as in other countries -- American unit banking laws led to a proliferation of geographically isolated banks in the United States. Coordination and coinsurance 
among a large number of banks is not feasible because of prohibitive costs of monitoring and enforcement and because the marginal benefit of monitoring a neighbor falls with the number of banks in a coalition. Thus American bank check clearing houses, like the earlier note clearing relationships, remained local in character.

The design of the Federal Reserve System reflected two perceived weaknesses of the preexisting payments system. First, the banking system had proved unusually susceptible to financial crises. Second, the "pyramiding" of reserves, especially the concentration of bankers' balances in New York City, seemed to some to give too much control over the banking system to New York's banks. As evidence of this concentration of power through reserve pyramiding, proponents cited non-par check clearing (just as the Jacksonians had criticized the discounting of bank notes). The Federal Reserve was organized into twelve separate districts in an attempt to reduce the concentration of power perceived in the private arrangements that banks established

Ironically, the concentration of reserves and power in the city clearing houses was reinforced rather than circumvented by the establishment of the Federal Reserve System. The chief benefit of membership in the system was access to the discount window, but the costs of membership -- in particular, higher reserve requirements -- led smaller banks to opt to continue to rely on correspondents in clearing transactions, depositing funds, and obtaining credit. White (1983) argues that larger banks were able to pass through much of the benefits of access to the Fed's discount window, allowing small banks to "piggy back" on large money-center banks without paying the high costs of Fed membership.

Various features of the way the Fed now manages the payments system depart from the practice of pricing services efficiently. Some of these procedures provide implicit subsidies to special interests within the Fed's membership (especially small, rural banks). For example, the Fed charges average, rather than marginal cost, in pricing its services. It does not offer volume discounts for clearing, and it sets a maximum price for many services (like physical delivery and pick up), which subsidizes those services to small banks in remote locations. The inefficiency of 
the Fed's payment system has helped to spur competing arrangements, which are becoming increasingly important.

The persistence of private interbank cooperation and correspondent relations in the payments system in the face of regulations designed to limit or abolish such relations indicates that coordination among banks did not solely serve the interests of money-center banks, and did not require coercion. It seems reasonable, then, to ask whether earlier forms of banking coordination primarily benefited large city banks or their country correspondents.

\section{The Two Views of the Suffolk System in Theory and History}

The Suffolk System is the clearest early example of a payments clearing network that was alternatively viewed as highly efficient or highly exploitative of small banks. In what follows we discuss these alternative theoretical perspectives and their representations in the historical debate that took place in New England and elsewhere over the desirability of a centralized and privately regulated payments system

\section{Theory}

According to the "jaundiced view" of bank cooperation, the profitability of banking coalitions derives from their ability to limit supply and engage in monopoly pricing. Any gains are at the expense of the public as a whole, and may accrue in particular to the large banks in the cooperative arrangement at the expense of the smaller banks.

The "sanguine view" argues that cooperative arrangements increase the efficiency of the banking system as a whole, so that the gains may accrue not only to the banks in the agreement -large or small -- but also to the public. In this section we will examine the arguments for the efficiency of private cooperative arrangements, and in particular, what advantages they may have over government regulatory alternatives. Recent arguments for the efficiency of historical interbank networks have been advanced by White (1984), Gorton (1985, 1989a and 1989b), Gorton and Mullineaux (1987), Mullineaux (1987), Calomiris and Kahn (1991), Calomiris (1989), and Calomiris and Gorton (1991). A common feature of these approaches is their reliance on 
interbank arrangements to economize on transactions and information costs. We will discuss their potential benefits in two areas -- first, as a means of providing stability during periods of financial stress, and second, as a means to clear payments during normal times.

Any cooperative arrangement to provide stability during periods of financial stress is fundamentally a matter of coinsurance. But this coinsurance can take many forms. In some cooperative arrangements, the coinsurance took the form of an explicit guarantee; in other cases, banks agreed to maintain markets in each other's liabilities for some interval of time at prespecified terms. In all cases, the ability to participate in coinsurance was contingent on the observance of explicit rules for behavior. These rules limited moral hazard problems and kept banks from free-riding on the risk-sharing benefits.

Insurance was useful in dealing with disturbances to illiquid bank loans. When the default risk of bank borrowers rose as a class, but the incidence of risk across banks was uncertain, depositors had reason to fear for the solvency of their own banks even if the size of the disturbance was small relative to aggregate bank capital. This uncertainty could cause even solvent banks to suffer in such circumstances. Coinsurance removed the incentive for preemptive runs by depositors, reduced the likelihood of costly financial crises, and thereby increased the demand for bank liabilities and the value of bank equity.

Besides reducing the likelihood and costs of financial crises, interbank coordination reduced transactions and information costs during normal times, as well. The simplest example is establishing rules for note or check clearing that allow banks to take advantage of economies of standardization and coordinate multilateral transfers of checks to reduce physical transactions costs. Such coordination should reduce banks' demand for costly reserve holdings as well, by increasing the predictability of check clearings. ${ }^{2}$

In addition to economizing on the physical costs of check and note clearing, bank coordination reduced information costs associated with making financial intermediation incentivecompatible and thereby increased the demand for bank notes and deposits. The essence of a banker's occupation is to specialize in gathering information that allows him to determine the 
optimal allocation of the investment funds at his disposal. Despite the obvious advantages of such specialization in information, the banker's superior information can create an incentive problem between banks and their depositors whenever there is a potential conflict of interest between them (as in Diamond, 1984).

Calomiris and Kahn (1991) show that demandable debt contracting with a "first come, first served" rule can provide a solution to this problem. Essentially demandable debt provides an incentive for the depositors with the lowest costs of monitoring the banker to do so. In bad states, informed depositors benefit by being first in line. Their run forces early closure of problem banks, benefiting depositors as a group. This triangular relationship among informed depositors, uninformed depositors and bankers economizes on the costs of gathering information and encourages financial intermediation.

In fact banks are the natural parties to act as informed depositors in enforcing discipline on other banks. Bankers are especially familiar with the business of banking and therefore have a comparative advantage in determining whether a run on another bank was called for. Nicholas (1907) stresses the role of other informed banks in forcing a bank's liquidation through deposit withdrawals when its prospects deteriorated. Furthermore, as Nicholas points out, the risk of unwarranted runs by uninformed depositors was reduced by the willingness of informed bankerdepositors to loan specie to threatened banks to stave off or reduce the costs of unwarranted runs.

In short, an agreement by one bank to place deposits in another bank is a voluntary bilateral relationship which helps to solve several incentive and insurance problems. Multilateral agreements among coalitions of banks allowed even greater opportunities to reduce the costs of financial intermediation. These came in several forms:

First, by agreeing on common standards for products, accounting, and business practices banks could reap economies of standardization.

Second, as emphasized by Calomiris and Kahn (1991), the attractiveness of a bank's liabilities may be enhanced by providing a mechanism for its liability holders to run the bank. Geographical distance can hamper a bank's ability to commit in this way, and it may be physically 
costly to set up redemption offices throughout the country. Thus banks may find it advantageous to maintain redemption facilities through other banks and thereby allow informed depositors early access to its reserves.

Third, by regulating or prohibiting certain activities and agreeing on reserve and capital requirements, banks could reduce the costs associated with monitoring one another. Here banks could trade off the advantages of reduced information-gathering costs against the costs of "inflexibility" associated with adherence to common standards of banking

Fourth, membership in a banking coalition provided a credible signal to uninformed depositors of a bank's quality, since the reputation of other banks was at risk if any bank failed to meet the announced standards of the group. Given the advantage of being a member of the coalition, the threat of being "thrown out" of the group was a powerful disciplinary tool In each of these cases the advantages described could also be obtained through a centralized govemment regulation. Common standards could be established by federal fiat as well as by voluntary coordination. Monitoring could be facilitated by prohibitions written into law as well as by prohibitions written into cooperative charters. Information on a bank's quality could be determined by announcing that the bank belonged to a standard-setting association of banks, or by announcing that the bank was in compliance with standards mandated by the federal government's bank regulators.

Nonetheless, in each of these cases, voluntary arrangements may have advantages over government regulation. If the banks reap the economies of standardization, if banks pay the costs of monitoring, or if banks suffer the penalty of the loss of the good name of their standard-setting association, then banks may have greater incentive than govemments to make sure the arrangements are efficiently formulated.

Banks may also be better than governments in ensuring that their arrangements have timely provisions in them. The effectiveness of cooperative bank arrangements in preventing malfeasance by individual banks was enhanced by the collective banks being able to "blow the whistle" on an individual even before formal legal procedures could be initiated. The testimony of regulators 
emphasized the importance of moving quickly to close troubled institutions, whose incentive to engage in risky practices increased during bad times. The speed with which coalitions of bankers acted against individual member banks contrasts with the deliberateness (sometimes described by current observers as "excessive forbearance") that is typical of publicly regulated regimes in this country.

\section{History of the Suffolk System}

The Suffolk System was the first significant coalition of banks in the United States. It spanned New England, giving it a wider geographical coverage than any banking coalition in the U.S. before or since. The purpose of the system was to establish a common currency area for member banks throughout New England. Banks made markets in each other's notes, and kept the notes trading at a uniform rate of exchange (par, for most of the period). Banks did not insure each other's notes, but they did face exposure to loss during the time interval it took to retum notes to their point of issue.

The System began in 1819 as an anticompetitive scheme by Boston's Suffolk Bank. Earlier the merchants of Boston had formed an association to pool "foreign" (out-of-Boston) bills and retum them to their banks of issue. In 1814 the New England Bank independently established bilateral relations with New England banks located outside of Boston, agreeing to make a market for peripheral banks' notes in Boston at specified discount rates of 1 percent or less, depending on the distance from Boston, and to accept the same discount rate upon redemption at the banks of issue. In retum the New England Bank required a permanent deposit from participating banks.

In 1819 the Suffolk Bank entered the same business, and offered similar or slightly better terms to participating banks, in some cases allowing banks to forego a permanent deposit so long as all their Boston deposits were placed with it. Seeking to expand its hold on the market, in 1824 the Suffolk Bank appealed to all Boston banks to finance a joint effort to retum the currency of New England banks that had not agreed to its terms.

With these added resources the Suffolk Bank was able to convince most banks in New England to accept its terms. In 1825 the arrangement was altered, with the Suffolk Bank receiving 
country money at par rather than at a discount, and participating banks agreeing to keep a permanent deposit (which varied with the bank of issue) at zero interest at the Suffolk Bank. Additional charges on notes redeemed would accrue if the amount exceeded the issuing bank's excess deposits at the Suffolk Bank - that is, the deposits over and above the permanent deposit. Notes would be returned to the bank of issue once a week, or whenever the total exceeded a fixed sum. The Suffolk Bank reserved the right to refuse to redeem notes whenever the total exceded the amount of the permanent deposit. As the flow of notes accelerated the Suffolk Bank further altered its plan. In 1831 it moved to daily, rather than weekly, redemption of accumulated notes, and in 1834 it limited the amount of a bank's notes redeemed without charge on a single day to onehalf the amount of its permanent deposit. While the system continued to evolve during its existence, it retained these basic features (see Whitney, 1878).

Mullineaux (1987) argues that the Suffolk Bank's "franchise" was valuable because the Suffolk Bank had superior information about bank note-issuing behavior. In particular, by making markets in banks' notes the Suffolk Bank was able to detect quickly whether a bank had increased its stock of outstanding notes excessively. Just as importantly, by operating a unified network, the Suffolk Bank was able to limit the amount of time it took bank notes to retum to their point of issue, which limited the riskiness of making markets in banks' notes. The velocity of clearings varied within the system, by bank of issue and over time, but throughout the 1840 s and 1850 s notes cleared roughly once each month or two.

The Suffolk System also involved portfolio monitoring and regulation. For example, in 1842 the Suffolk Bank wrote to the President of the Bank of Woodstock to complain that "too large a portion of your loan is in accommodation paper [loans to industry], which cannot be relied upon at maturity to meet your liabilities..." (Whitney, 1878, p. 35). In a letter to the Eastem Bank of Bangor, declining to permit an expansion of overdraft credit, the President of the Suffolk Bank wrote that "I can only say that if all the banks in New England were moving on at the same rate you are, it would require more than all the capital of the banks in this city to supply their wants" (Whitney, 1878, p. 38). 
One of the most interesting aspects of the Suffolk System was the way it encouraged diligent monitoring by the individuals who managed the payments system. Throughout most of its history the Suffolk Bank's Cashier, William Grubb, managed the System. He began in 1824 earning a salary of $\$ 720$ per year. After experiencing some losses on bank notes in 1826 , the Suffolk Bank entered into a new agreement with Mr. Grubb, whereby he would eam \$1,050 per year in addition to his salary. In return, Mr. Grubb agreed to "give bonds to indemnify the bank for all deficiencies, counterfeits, mutilated or uncurrent bills in his department" (Whitney, 1878, $p$ 18). After a few months, Mr. Grubb complained that the increase in the volume of note clearings made a new arrangement necessary, and the Suffolk Bank increased his bonus to $\$ 4,250$ per year In exchange, he not only indemnified the bank against loss, but also bore the expense of paying the employees in the "foreign money department." In 1841 a $\$ 1,040$ loss was charged to Mr. Grubb in accordance with the arrangement. Grubb's salary rose from $\$ 10,800$ in 1846 to $\$ 20,000$ in 1849 By 1854 -- in response to the continuing increase in note clearings -- Grubb's annual compensation had risen to an astounding $\$ 30,000$ per year (roughly half a million 1995 dollars).

It is not possible to gauge how much of his salary Grubb retained after normal expenses (owing to a lack of detailed records on clearing expenses). What is clear is that losses on notes were a small portion of his total compensation. From 1836 to 1850 , Grubb was charged a total of only $\$ 4,462$ under the indemnity agreement. Other employees of the foreign money department operated under similar bonding arrangements. In one case, a careless teller was responsible for an error of $\$ 2,933$. One thousand dollars of that cost was borne by the indemnity bond of the employee, and the remainder by Grubb (Whitney, 1878, p. 40).

Clearly, accountability and incentive compatibility were well understood by designers of the Suffolk System. They were similarly ingenious in their method of discouraging counterfeiting. As recounted in Hunt' Merchants' Magazine (v. XXVII, p. 223):

The Suffolk Bank of Boston...has devised a method of checking to a great extent the passing of bad money. In their foreign department there are daily received from the different banks in New England, large numbers of counterfeit bills. These, of course, are retumed as worthless, but before this is done, a description is taken of each, with the name 
of the depositor, which by bank laws is always placed on the band of each parcel. On the back of the bill is marked the date and a reference letter, and the bill is then retumed. Should it again be put in circulation, the person who receives it has but to call at the Suffolk Bank, and he can ascertain through whose hands it has passed, and oblige the party to make it good, the record of the Bank being sufficient evidence to force redemption.

With respect to handling financial crises, the Suffolk System did not provide lender of last resort services or note insurance. While we have argued that the Suffolk System may have limited the likelihood of financial crises and their costs, it was not a coinsurance arrangement designed to resolve or absorb the costs of financial crises, as were some later bank clearing houses or the mutual-liability systems of Indiana, Ohio, and Iowa. Boston banks' risks of loss were limited to defaults on overdrafts, and overdrafts were limited in quantity and could be denied altogether Nevertheless, there were risks of loss to Boston banks, and losses did occur during the Panic of 1837. In order to reduce these losses the Suffolk System relied on set standards for member banks, and monitored their compliance with those standards.

As the volume of banking activity continued to grow, other banks in Boston and other New England cities became partners in the business of redeeming notes. Each stood ready to receive its own correspondents' notes or any other's correspondents' notes at par. ${ }^{3}$

\section{Contemporaries' Views}

The sanguine and jaundiced views of bank coalitions were well represented in the qualitative evidence collected by contemporary accounts of the Suffolk System. Hunt's Merchants' Magazine often published impassioned defenses of the System as well as attacks upon it (in particular, see the lengthy exchange in v. XXIV)

Clearly the Suffolk Bank's initial intentions were not altruistic; its goals in founding the system were to limit competition from peripheral banks and to profit from forced deposits. In its 1824 appeal to other Boston banks it argued that Boston banks could increase their share of the loan market by forcing the contraction of the country banks. The 1824 redemption campaign prompted a "bank war" in New England in which the Suffolk Bank used the threat of random redemptions of large amounts of notes to coerce banks to join its system. In a famous incident with the Worcester Bank it even refused a check drawn on the New England Bank and specie delivered 
in Boston as payment for notes, insisting instead on specie payment at the point of issue, in strict accordance with the law (Dewey, 1910, p. 85). In this case, the Suffolk Bank clearly was selling "protection" against its own threats.

The continuing animosity of country banks was exemplified by the following complaint to the legislature in 1835, lamenting the Suffolk Bank's monopoly power:

After the legislature has granted a charter to a bank, before such corporation dare to go into operation or issue a single dollar (bill), it must send a deputation to Boston, and laying down the bags of tribute money at the feet of the president of the Suffolk Bank, receive from his permission and the terms upon which it may operate (Knox, 1907, p. 332).

On the other hand, many sanguine observers commented that the discipline brought by the Suffolk Bank increased the demand for country banks' notes, allowing their quantity to increase and their discount rates to fall. As early as 1819 it was recognized that the competition between the Suffolk Bank and the New England Bank acted generally to reduce the discount rates on country bank notes. Banks in Maine that did not participate in the system found a limited market in their notes in New England. Banking commissioners in Connecticut and Maine praised the Suffolk System in 1842, arguing that it provided necessary discipline and was responsible for New England's unusual stability during the Panic of 1837 . In Vermont, the state government went beyond praise. In 1842, Vermont passed a law requiring its banks either to join the Suffolk System or pay a one percent annual tax on bank capital. By 1850 , all of Vermont's banks had joined the System (Knox, 1900, p. 356).

Advocates of the Suffolk System argued that Boston banks soon realized that their goal of limiting competition in the loan market was not achievable and that the main benefit to them of the arrangement came from the interest-free deposits of country banks in Boston. Over time, the potential for seignorage rent earned by the Suffolk Bank and other Boston banks fell as competition intensified. As early as 1841 , a commentator in Hunt's Merchants' Magazine (V, p. 262) claimed that country banks' profit rates on note issues were higher under the Suffolk System, arguing that the expenses of membership were more than offset by the profits which came from the reduced discount rate on notes. 
In summary, while historians have disagreed about the precise division of rents between city and country banks, and about the effects of the system on country bank note issues, they agreed that the system was effective in creating a uniform currency area throughout New England and in promoting stable banking due to the disciplinary role of the Boston banks. As the 1878 Report of the Comptroller of the Currency observed: "The country banks kept their circulation as extended as possible for their own profit. Their overdrafts on the Suffolk enabled them to do so, but at the same it put them completely into its power" (Dewey, 1910, p. 96).

\section{Quantitative Predictions of the Two Views}

It is possible to go beyond these qualitative assertions to discover whether (and to what extent) the Suffolk System operated as a vehicle of redistributing rents from country banks to city banks, or as a vehicle for increasing the demand for the bank notes of all participating banks by lowering default risk through self-regulation. The two views have different implications for observable bank behavior.

First, both the jaundiced and sanguine views predict lower observed discounts for country bank notes, but for different reasons. According to the jaundiced view, large banks constrained small banks' ability to issue notes, thus preserving a note issuing monopoly for themselves and keeping the aggregate supply of notes low and their "price" (the inverse of their discount rate) high. According to the sanguine view, small bank note discount rates were associated with outsiders' confidence in the banking system's abilities to limit note risk. Note risk reduction, in this view, was achieved through collective protection (reduction in systemic risk) and the discipline imposed by banks on each other's portfolio choice. Thus it is necessary to examine both the discount rate and the volume of notes issued by banks (normalized by population, wealth, or income) to sort between the two views. 
Second, the two views differ with respect to the relative quantities of notes issued by city banks and country banks in New England. According to the sanguine view, improvements in the system should have helped country banks more than city banks to increase their notes in circulation. In contrast, critics of the Suffolk System alleged that it led country banks to contract their note issuing and allowed city banks to expand their notes in circulation. Thus city-country comparisons provide an additional test for the two views.

Third, the two views have different implications for the magnitude of the rents enjoyed by Boston banks. According to the jaundiced view, Boston banks' market value should reflect substantial rents that accrue to the banks as a result of their monopoly position in the note market. According to the sanguine view, Boston banks should not capture significant rents from note issuing. Thus an examination of the charter values of Boston banks could shed light on the relative merits of the two views

Fourth, the two views make different predictions about bank capital ratios and reserve ratios. According to basic finance theory, capital and reserves serve as two alternative risk buffers to insulate note holders and depositors from default risk that originates in the bank's portfolio of risky assets. If the Suffolk System provided an effective means to reduce systemic risk and discipline banks' portfolio choices, then New England banks should have been able to satisfy noteholders and depositors of banks (keep bank default risk low) with lower amounts of reserves and/or capital. If, instead, the Suffolk System was a means for city banks to threaten country banks with city bank-orchestrated runs on country banks, then the reserve ratios of country banks should have been high to protect against such a threat. 


\section{$\underline{V . D a t a}$ and Sources}

To address these questions we construct controlled comparisons between the banking system of New England and the banking systems of other Northeastern states. We pursue three levels of data analysis: comparisons at the state level across banking systems, comparisons of the relative performance of urban and rural banks within the two systems, and the characteristics of individual banks in New York City and Boston. To judge whether the Suffolk System produced higher or lower aggregate note issue, higher or lower country bank note issue, large note-issuing rents for Boston banks, and higher or lower reserve and capital ratios we employ performance measures for Northeastern states (as a whole or divided according to urban and rural) and for New York City, in particular, as the benchmarks against which we measure the effects of the Suffolk System. Our sample of states includes the eleven northeastern states, from Maryland to Maine To perform these comparisons we draw on data from bank balance sheets and stock prices, as well as bank note discount rates and census data on population, wealth, and income. We focus our comparisons on the years around 1850 (1850-1853). This choice has several advantages. First, the availability of banking data are greater for the 1850 s than for earlier periods. Second, later data are not useful for our purpose. By the late 1850 s, the comparison between the Suffolk System and other Northeastern states is no longer possible. The Suffolk System was replaced, in part, by the Bank of Mutual Redemption (which began operation in 1858), and New York City, Baltimore, and Philadelphia all developed interbank cooperation to some extent through clearing houses by the end of 1858 . Third, the early 1850 s were a time of sustained calm in the economy and in the banking system (unlike the years $1837-1842$ and 1857-1858). Thus it is reasonable to argue that bank balance sheets during the early 1850 s reflected equilibrium choices of banks, and it is reasonable to assume (as we do) that the fundamental risks associated with lending were stable 
during our period. Finally, 1850 is a census year, enabling the construction of measures that control for population, income, and wealth.

Our data sources are as follows. For bank stock prices and dividends, we use data reported from Hunt's Merchants' Magazine, which reports monthly stock price data for five New York City banks in 1853 and for all Boston banks in 1850. We searched Shipping and Commercial List for 1853 for additional New York City bank stock observations, and were able to add two more observations from that source. Our data on bank balance sheets are from state banking reports, which were published in the Executive Documents of either the House of Representatives or the Senate each year after 1836. Note discount rates are New York City prices from Thompson's Bank Note and Commercial Reporter. These discount rates represent actual transaction prices in the market for bank notes. Census data are from the Compendium of the Census (1850) and Tucker's Progress of the U.S. in Population and Wealth (1855).

\section{$\underline{\text { VI. Results }}$}

\section{Discount Rates on Bank Notes}

By 1850 , all banks operating in New England enjoyed par convertibility within the region Outside the region -- in Philadelphia and New York City -- the notes of New England banks received a uniform discount rate, which was lower than any other states in the nation. For example, New England bank notes traded at lower discount rates in New York City (1/8 of one percent) than did the notes of New York state banks located outside New York City.

Few states, and no regions in the country, enjoyed New England's uniformity. Those states that did achieve uniformity shared the self-regulatory features of the New England system (Calomiris and Schweikart, 1988, 1991). For example, Ohio's mutual liability system and the branch banking systems of Virginia and South Carolina acted as self-regulating coalitions of 
banks, particularly during the Panic of 1857 , and also enjoyed uniform and low bank discount rates in New York and Philadelphia. In a formal study of bank note discount rates, Gorton (1989a) shows that low discount rates for Suffolk System states reflected low region-specific note default risk, even after controlling for distance from point of issue and the risk-reducing influences of capital and reserves in bank balance sheets.

\section{Note Circulation}

As argued in section IV, both the sanguine and jaundiced views are consistent with low discount rates on bank lending, but they differ with respect to the predicted volume of note issues, the locational distribution of note issues, specie and reserve ratios of banks, and rents from note issues. Data for the basic balance sheet categories of banks in the eleven Northeastern states in 1850 are reported in Tables I and II, with breakdowns in some states that divide banking data by city and country banks. The cities in our sample are Boston, Providence, Philadelphia, New York City, and Baltimore.

Table I lists bank reserve assets. The main categories are specie, notes on hand from other banks and deposits held in other banks. We have also reported "specie funds," a reserve asset category in some states and therefore a close substitute for specie. We have not reported loans outstanding as a separate category; most of the difference between specie and total assets represents loans. The only other category of significance which is not reported is real estate holdings, the precise meaning of which was not clearly comparable across states.

Table II lists net worth and liabilities. The major categories of liability are the banks own notes in circulation and deposits. Most of the states' balance sheets allow deposits to be subdivided into deposits owed to the public and deposits owed to other banks. The exception is New Hampshire; however, it is likely that the deposits of other banks in New Hampshire banks were negligible, so that little damage is done by omission of this variable. 
When examining the propensities of banks inside and outside of the Suffolk System to issue notes, one must control for demand-side factors that could explain differences in the amount of notes outstanding. To do so we normalize note issues by various measures: population, urbanization, income, and wealth.

Table III examines the note circulation of banks normalized by population. With the exception of the highly rural states of Maine and New Hampshire, the volume of note circulation of banks per capita is higher in New England than in the Middle Atlantic. For both regions, circulation per capita is highest in the major cities. When one compares banks outside of major urban areas in the Middle Atlantic and New England, New England's banks display much higher per capita circulation of notes. Excluding Boston and Providence, Massachusetts and Rhode Island banks show per capita circulation that is roughly 50 percent higher than that of New York state outside of New York City, twice as high as that of New Jersey, three times as high as Pennsylvania outside of Philadelphia, and four times as high as Maryland outside of Baltimore. Even the most rural New England banks -- in Maine and New Hampshire -- maintained per capita circulation that exceeded those of rural Maryland and Pennsylvania

Figure 1 illustrates the differences in per capita note circulation as a function of the percentage of each state's population living in an urban location (defined as a city with a population of at least 2,500 ). Figure 2 provides the same information, but separates large cities from the rest of the locales in the states that contain large cities. The boxes in Figure 1 denote states or parts of states which are located in New England. The crosses denote states or parts of states that are located in the Middle Atlantic. The plots show that per capita note circulation increase with urbanization. It is also clear that, adjusting for this effect, the Suffolk System had higher per capita note circulation than did the Middle Atlantic states. 
Table IV provides similar data on note circulation of banks normalized by state income. The interstate differences are similar to those reported in Table III, but less pronounced, as some of the differences in note circulation per capita are explained by differences in income per capita. New England enjoyed annual income of $\$ 84$ per capita, compared to $\$ 76$ in the Middle Atlantic. We also include data on circulation as a fraction of nonagricultural income. Given our finding that note circulation is lower per capita in rural areas, one might argue that the percentage of urban income in a state increases the demand for bank notes. Table IV shows, however, that even if one wished to argue (unrealistically) that notes were exclusively required to facilitate nonagricultural transactions, New England's banks still tend to exhibit higher note circulation relative to nonagricultural income.

Alternatively, as shown in Table $\mathrm{V}$, if one normalizes bank note circulation by wealth (the market value of the sum of real estate and personal estate) rather than by income, the differences in circulation between New England and the Middle Atlantic remain. Normalizing by wealth, the rural New England states of Maine and New Hampshire display higher circulation than the rural states of New Jersey, Maryland, and Pennsylvania. Massachusetts, Connecticut, Rhode Island, and Vermont maintain higher circulation relative to wealth than New York state. Not surprisingly, tiny Delaware, a state with low per capita income and per capita wealth located at the crossroads of four of the largest commercial centers in the country (New York, Philadelphia, Baltimore, and Washington), displays unusually high circulation as a fraction of wealth.

To summarize, irrespective of how one controls for influences on the demand for the circulation of banks, two conclusions emerge: New England's banks tended to issue more currency than banks in the Middle Atlantic, and rural regions of New England issued more currency per capita than rural regions in the Middle Atlantic states. Thus, not only did the Suffolk System promote lower note discounts, but it did so by encouraging greater circulation by both urban and 
rural banks in New England. These facts lend strong support to the view that the Suffolk System increased the efficiency of the banking system, and did not operate as a means to constrain the note issues of banks outside Boston.

\section{Reserve Ratios and the Threat of Interbank Runs}

Tables VI and VII examine the specie ratios of the banking systems in our sample. Several pattems emerge. First, the ratio of specie to bank liabilities (using various measures) is smaller in the New England states than in the Middle Atlantic states. In other words, the public willingly held notes and deposits in the Suffolk System banks with a lower proportion of specie backing than in the non-Suffolk System states. (Had we included specie reserves along with specie the results would have been even more dramatic.) A similar story is told by an examination of specie as a fraction of total reserve assets. The fraction of reserve assets held in specie is lower in New England than in the Middle Atlantic.

How should one interpret differences in specie-to-liability or specie-to-reserve ratios? From an individual bank's standpoint, specie is the most expensive form in which to hold reserves, since it bears no interest. But specie can be uniquely useful to banks, since it is the legally mandated form of payment for noteholders or depositors seeking to withdraw their funds. A high specie-to-reserve ratio, therefore, reflects the need to protect against withdrawal risk. It follows that New England banks were less worried about withdrawal risk than Middle Atlantic banks.

Most importantly, the ratio of specie to liabilities and the ratio of specie to total reserves are low for New England banks operating outside of Boston. It seems that these banks were able to achieve the large outstanding circulation noted above without having to maintain large stocks of specie to protect themselves from potential runs orchestrated by Boston banks. In other words, if Boston banks were threatening other banks with runs as a means to limit peripheral banks' circulation, one would expect peripheral banks to maintain unusually large stocks of specie to 
defend themselves against such a threat. The data on specie holdings, however, runs counter to this view. Peripheral banks in New England maintained lower specie, both as a percentage of assets and as a percentage of reserves.

It is worth noting that New York state's laws limiting interbank note redemption, and requiring peripheral banks to maintain convertibility of notes in New York (via interbank deposits with New York City banks), affect the ratios of specie reserves of both peripheral banks and City banks in New York. Because the law protected peripheral New York banks from sudden withdrawals of notes, they enjoyed the lowest specie reserves of any banks in the country (at two percent of total assets). That law required them to maintain convertibility of their notes in New York City. New York state banks located outside the City held interbank deposits equal to nearly ten percent of total assets, which was comparable to the proportion of interbank deposits relative to assets held by Massachusetts banks located outside of Boston.

The key difference, however, between the Massachusetts and New York banks was the effect of the two regulatory regimes on the public's willingness to hold their notes. As discussed above, peripheral New York banks had low circulation per capita (7.9) compared to peripheral Massachusetts banks (17.5), and saw larger discounts on their notes in New York City than did New England banks. Thus the New York regulation's limits on the potential for market discipline over peripheral banks economized on bank specie holdings, but probably limited the demand for peripheral bank notes.

\section{Payments System Risk Reduction and the Suffolk System}

Low specie reserve holdings in New England argue against the view that country banks lived in fear of runs by Boston banks. It is tempting to also conclude from the low reserve ratios that the Suffolk System allowed banks to operate more efficiently (with lower deadweight costs of reserve holdings) because of the credible discipline imposed by the interbank network. According 
to this argument, banks operating in a system that controls their portfolio choices and regulates interbank clearing can attract depositors and noteholders without holding as much in reserves.

The lower propensity of New England banks to fail relative to those in the Middle Atlantic also points toward the possible stabilizing influence of the Suffolk System. From 1840 to 1860 , only 47 banks failed in all New England. As in other regions, a large proportion of failures occurred during the Panic of 1857, but in New England the effects of the Panic were relatively mild. Only fifteen banks failed in New England as the result of the Panic. All but three of these were very small banks (with capital under $\$ 200,000$ ), and the other three were banks of moderate size. According to Root (1901, p. 223), the estimated losses to noteholders in failed New England banks as the result of the Panic were small -- only $\$ 133,000$, which represented 0.9 percent of failed banks' outstanding notes, and roughly 0.03 percent of the total stock of New England bank notes in circulation in 1857. Bank failure rates and noteholder loss rates were significantly higher in the Middle Atlantic states (Calomiris and Schweikart, 1988, 1991). The Massachusetts Bank Commissioners Report of 1858 describes the resilience of its banks in the face of the Panic of 1857, which was associated with widespread suspensions and bank failures in the Middle Atlantic:

Your commissioners cannot refrain from remarking upon the very satisfactory condition presented by the banks of the Commonwealth, after the severe commercial crisis through which the community has just passed. Although driven into the suspension of specie payments, through the action of foreign [i.e., New York City and Philadelphia] institutions, still they never for a moment lost the confidence of community as to their soundness, nor did they fail, during the period of alarm, to furnish every accommodation to their customers which could justly be expected. In fact, some of our banks did not suspend at all, not even in form; and, with a large part of them the suspension was merely nominal...in very few instances was specie positively refused... That the confidence in the strength of our banking institutions was well founded...is fully evinced by their prompt resumption of specie payments, and by the comparatively small amount of overdue or suspended paper with which [their customers] were burdened (Root, 1901, p. 220).

Reserve ratios and bank failure rates, by themselves, however, are insufficient evidence that the risk-reducing discipline of the Suffolk System decreased bank failure rates or the need for banks to use reserves. The reason reserve ratios by themselves provide insufficient evidence is that 
reserves are only one of two ways to insulate noteholders and depositors from risk. The other risk buffer is capital. If New England banks financed with more capital than did banks outside of New England, then it may be that their lower reserve ratios reflect capital differences rather than loan risk (or payment system risk) differences. Similarly, New England banks' lower failure rates may have reflected higher capital ratios, rather than lower loan risk or payment system risk.

In fact, New England banks maintained significantly higher capital ratios than other banks. As shown in Tables III-VII, capital ratios in New England are higher relative to bank liabilities, population, state wealth or state income, and bank capital ratio differences between New England and the Middle Atlantic are not explained by urbanization (Figures 3 and 4).

Part of the explanation for high capital in New England may be regulatory limits on debt financing. As of 1850, according to Dewey (1910) and Root (1901), capital regulations in Massachusetts banking law required that banks limit their note circulation to 125 percent of capital. According to both of these sources, as of 1850 , Vermont's law limited bank note issues to twice paid-in capital. According to Root (1901), Connecticut's banks were required to restrict note issues to 150 percent of capital, while according to Knox (1900), circulation was limited to 150 percent of the combined amounts of capital and deposits. According to Root and Dewey, Rhode Island's banking law limited note issues to a maximum of 75 percent of capital (for the smallest banks), and the permissible ratio of notes to capital fell with bank size to a low of 20 percent for the largest banks. In New Hampshire, according to Knox, note issues were limited by an 1842 change in law to 80 percent of paid-in capital. According to Dewey and Root, in 1846 Maine limited circulation in excess of 50 percent of capital to three times specie holdings, and limited the total amount of circulation to the sum of capital and specie reserves. Clearly, strict limitations on bank note issues or total debt could help to explain the high capital ratios of New England's banks 
In addition to regulatory influences, the relative maturity and liquidity of Boston's stock market may have favored the reliance on capital rather than reserves as a risk buffer for bank liabilities. This is not necessarily an exogenous factor with respect to the banking system. It may have been that the discipline afforded by the Suffolk System facilitated the flotation of New England bank stock.

Regardless of the source of high capital in New England's banks, the large differences in capital ratios between New England and the Middle Atlantic must be taken into account when measuring the risk-reducing benefits of the Suffolk System. To determine whether the Suffolk System promoted confidence in banks on the part of noteholders and depositors one must look at the combined effects of bank capital and reserves. It must be shown that New England banks were able to hold a lower combination of reserves and capital than Middle Atlantic banks. To make this argument, one must posit a model of the substitutability between capital and reserves as risk buffers for bank liabilities. The basic finance theory that can be used for this purpose comes from the literature on the pricing of contingent claims (which is founded on the Black-Scholes option pricing model).

As noted above, Gorton (1989a) uses contingent claims theory to argue that the discount rates on New England banks' notes in New York or Philadelphia were unusually low. That is, after taking account of the effect of distance on discount rates, and the risk-reducing effects of capital and reserve ratios, New England banks' notes had lower discount rates than banks located in other regions. Our exercise is similar in spirit to Gorton's but it overcomes a potential problem with his approach. Gorton controls for the effect of capital ratios using book rather than market value measures of equity. To the extent that Boston banks' stock values exceed book value, their true equity ratios could be larger than those assumed by Gorton, and this could provide an alternative explanation for Gorton's findings. Gorton's work also relies on aggregate bank data at 
the state level, which given non-linearities in option pricing can introduce aggregation bias into the measurement of bank risk.

To overcome this problem, we collected data on bank stock prices and dividends, as well as bank balance sheet data for individual banks in New York City and Boston (for which stock price data are available for a substantial number of banks). Our approach is to derive outsiders' perceptions of the fundamental risk associated with banks' risky assets portfolio (the sigma of the loan portfolio) from the portfolio structures of banks and the variance of their stock prices. For New York, we use balance sheet data for December 3, 1853 and monthly stock prices for the 1853 calendar year. For Boston, we use balance sheet data for the first week of September, 1850 and monthly stock prices for the 1851 calendar year. These choices reflect current data availability constraints. Obviously, it would be ideal to compare data of identical timing, and we continue to pursue this possibility. Nevertheless, the period 1850-1853 was part of a long-lived macroeconomic expansion, and therefore, we think that the underlying riskiness of lending opportunities throughout the period was roughly similar.

We assume that because bank liabilities are withdrawable on demand ("putable") their market value and face value are essentially identical (i.e., in equilibrium, banks choose capital ratios and reserve ratios that result in near-zero default risk on bank liabilities). That assumption is upheld by data on bank note discount rates, which remained very small even for notes trading far from their point of issue (Calomiris and Schweikart, 1988, 1991, Gorton, 1989a). We also assume that reserves are riskless assets. Since reserves are composed of specie plus the demandable debts of other banks, this is a reasonable assumption. It follows that the market value of bank assets is equal to the sum of the face value of debt and the market value of equity. The market value of risky assets is equal to the difference between the market value of assets and the face value of bank reserve assets. 
Under these assumptions, one can derive measures of the stock market's view of the underlying riskiness of bank assets (the sigma of the loan portfolio) using the following equation:

Loan portfolio sigma $=$ (equity value /oan portfolio value) $x$ (standard deviation of stock returns)

Stock returns are defined to include both dividends and capital gains. Table VIII reports data on the loan portfolio sigma for New York City and Boston banks. As the table shows, the average or median estimated sigmas are much larger in New York City than in Boston. Size effects do not explain this difference. New York banks are larger than Boston banks in the sample, but in any case, bank size is uncorrelated with sigma. Three interpretations can explain the result of higher sigma for New York banks. First, it may be that the fundamental (exogenous) riskiness of lending in New York is much higher. Second, it may be that interbank discipline via the Suffolk System restricts banks portfolio choices in a way that reduces loan portfolio risk. Third, it may be that the Suffolk System itself reduced the risk banks faced from making risky loans. For example, coordination of the payments system by the banks may have been associated with greater interbank protection (for example, Boston banks may have protected sound banks somewhat from the possibility of unwarranted withdrawals by uninformed claimants of the bank). The second and third interpretations would be consistent with the sanguine view of the Suffolk System as a device for improving bank efficiency. Given the large difference between loan sigmas in New York and Boston, it seems reasonable to ascribe at least some of that risk difference to the operation of the Suffolk System

\section{Profitability and Rent Extraction by Boston Banks}

The jaundiced view of the Suffolk System implies that Boston banks earned substantial rents from their position as the managers of the payments system. In Table IX, we report available 
data from Hunt's Merchants' Magazine on average semiannual dividend payments of different sets of banks, within and outside New England, over the years 1831-1857. Dividend payments are expressed as a percentage of bank paid-in capital. During our period banks tended to retain very little of their profits, and so dividend payments are a reasonable measure of bank profitability.

These data indicate that bank profits for Boston banks were comparable to profits earned in Providence, in Massachusetts outside of Boston, and in Maine. Boston dividend ratios appear lower than those of New York City or Philadelphia during the late 1840s and early 1850s. Given that Boston banks had higher capital ratios than New York or Philadelphia banks, it is possible that the lower retums in Boston reflect lower risk to Boston bank stockholders (which is consistent with the observed differences in stock retum risk between Boston and New York City banks, described in Table VIII). Overall, these data do not provide support for the view that Boston banks extracted abnormal profits as the result of their control of the Suffolk System

Perhaps a more convincing test of the presence of rents in Boston banks is an examination of their market-to-book value of equity ratios. If a bank has access to rents, those rents should be capitalized in the value of the bank's charter, and should lead to a higher observed ratio of marketto-book value of equity. Table X reports market-to-book value of equity ratios for Boston and New York City banks. The balance sheet data for Boston are for September 1850, with stock prices from the end of December 1850. For New York City, balance sheet data are for December 3,1853 , with stock prices from December 3, 1853 or the nearest possible date of a reported stock price between October 29 and December 28.

Banks for which charters are of little value will maintain market-to-book ratios near one Ratios of the market-to-book value of equity less than one may indicate that some loan losses either have occurred or are expected to occur. These data indicate that the charter values of Boston 
banks were negligible, given an average market-to-book value of equity ratio of 0.948 . The Boston ratios are comparable to, though somewhat smaller than, those of New York City banks.

Could it be that only the largest Boston banks were able to extract rents from controlling the payments system? The data do not support that prediction either. Three Boston banks had total book value of assets greater than $\$ 2$ million: Merchants' Bank (with $\$ 6$ million in assets), State Bank (with $\$ 3$ million in assets), and Suffolk Bank (with $\$ 3.8$ million in assets). The marketto-book value of equity ratios for these three banks were $0.955,0.935$, and 1.002

\section{Conclusion}

In this paper we take a close look at the operation of the first privately regulated payments system in the United States, New England's Suffolk System. We contrasted two views of the system. According to the sanguine view, the system enhanced bank efficiency, while according to the jaundiced view it was a means used by large banks to extract rents from small banks.

Our evidence provides substantial support for the sanguine view and no support for the jaundiced view. Compared to banks operating in the Middle Atlantic (outside the system), New England's banks were able to issue more notes, and these notes traded at uniform and low discount rates compared to those of other banks. An examination of the balance sheets and stock returns of Boston and New York City banks indicates that the stock market perceived that bank lending produced less risk for bank debt holders in Boston than in New York. The benefits of the system extended outside of Boston. Peripheral New England banks displayed high propensities to issue notes, and were able to maintain low specie reserves. The Boston banks that ran the system did not exhibit high profit rates or high ratios of market-to-book values of equity; thus there is no evidence that Boston banks extracted rents from their control of the payments system. 
Federal policy toward the payments system increasingly has reflected concerns about the connection between payments system relationships and bank competition. "Jaundiced" federal policies began in the context of antebellum note clearing and continued with the creation of the national banking system, the establishment of the Federal Reserve System, and the passage of the Banking Act of 1933. The tendency in all these instances is toward controlling or eliminating private interbank clearing networks.

Private clearing networks are staging a comeback currently. Our findings with respect to the operation of interbank clearing arrangements of the nineteenth century suggest that cooperation among clearing agents may serve a useful role in the resurgence in privately controlled clearings There seem to have been visible advantages, in the form of enhanced stability and greater liquidity, to allowing clearing agents to cooperate and regulate one another. Concerns about the use of regulations developed within clearing networks to inhibit entry or redistribute rents -- which were a common criticism of early private clearing networks -- are generally not supported by available data.

While our findings do not prove that clearing networks are immune to such problems, they provide an example of an efficient clearing system that was falsely presumed to have been a rentseeking device. The lesson for the future is that the potential benefits of peer regulation and peer monitoring among participants in the payments system may be large, and that such regulations may be motivated by efficiency rather than rent seeking. 


\section{NOTES}

${ }^{1}$ Redlich (1968, p. 78 ) pointed out that by the middle of the 1820 s, country banks were allowed to redeem their notes in New York City banks in funds instead of in specie. As a consequence, most payments by country banks were paid out of the credit which they had with their New York City correspondents, making the system collapse quickly. Lake (1947) suggested that it was this experience which induced the Suffolk System to insist on payment in specie of the notes of the New England country banks. However, no city bank made the initial step to set up a duplicate of the Suffolk Bank in New York. On April 4, 1840, the New York legislature made a law requiring that the banks of the state redeem their notes at $1 / 2$ percent discount either in New York City or in Albany. This legislation was not enough, and after various proposals had been made, the Metropolitan Bank of New York was chartered in 1851 for the purpose of copying the Suffolk Bank system in that city. Redlich (p. 80) notes

The differences between the New England and New York systems on the other hand are obvious: There, exclusively an achievement of private enterprise; here, very much the result of legislative actions which determined business policy. There, a par collection system; here, a system of collection at a discount. There, a monopolistic; here a competitive business. There, the issuing country banks alone bore the burden, while the monopolistic clearing house (the Suffolk Bank) alone made a profit, although the cooperating city banks enjoyed considerable indirect advantages; here, a wider public bore the burden, while issuing banks and redemption agents made some profit. In consequence of these differences the issuing banks in New England grumbled against their monopolistic clearing agent, while in New York it was the banks which had to take country notes on deposit that felt aggrieved. The result was similar: hardly had the Bank of Mutual Redemption come into existence, when the underlying idea migrated from New England to New York.

${ }^{2}$ If each bank experiences exogenous random demands for withdrawals and random supplies of deposits, an increase in daily "throughput" reduces the inter-day variation in net withdrawals, and thereby reduces the bank's demand for reserves, as in Miller and Orr (1957).

${ }^{3}$ Ultimately, conflicts between the Suffolk Bank and other banks arose over who would decide how to regulate the system. In 1852, after the Suffolk Bank responded to increased 
clearings with an increase in the fees on Rhode Island bank clearings, the Rhode Island banks objected and began to consider forming their own payment system. Further problems arose between the Suffolk Bank and the other Boston banks in 1853, when the Suffolk Bank limited the hours for clearing notes and altered its rules to ensure that the Suffolk Bank did not bear default risk on the country bank notes cleared through other Boston banks. Lake (1947) argues that these conflicts were a response more to the autocratic methods of the Suffolk Bank than to substantive objections to its rules.

In 1856, competition came from the Bank of Mutual Redemption, formed as a region-wide cooperative clearing house for bank notes on the same principle as the Suffolk System. After receiving admission to the Boston clearing house, the bank began operating in 1858 . It was owned collectively, with no member allowed to own more than 5 percent of its capital. Lake (1947) argues that the Bank of Mutual Redemption was a less effective system for controlling default risk on notes, and that this was reflected in the fact that roughly half of its respondent banks chose to remain with the Suffolk Bank after the entry of the Bank of Mutual Redemption. 


\section{REFERENCES}

Calomiris, Charles W. (1989). "Deposit Insurance: Lessons from the Record," Federal Reserve Bank of Chicago Economic Perspectives (May/June): 10-30.

Calomiris, Charles W. and Gary Gorton (1991). "The Origins of Banking Panics: Models, Facts, and Bank Regulation," in R.G. Hubbard, ed., Financial Markets and Financial Crises, Chicago: University of Chicago Press: 109-173.

Calomiris, Charles W. and Charles M. Kahn (1991). "The Role of Demandable Debt in Structuring Optimal Banking Arrangements," American Economic Review 81 (June) 497 513.

Calomiris, Charles W. and Larry Schweikart (1988). "Was the South Backward?: North-South Differences in Antebellum Banking During Crisis and Normalcy," Working Paper, Federal Reserve Bank of Chicago.

Calomiris, Charles W. and Larry Schweikart (1991). "The Panic of 1857: Origins, Transmission, and Containment," Joumal of Economic History 51 (December): 807-834.

Cannon, James G. (1908). Clearing-Houses: Their History Methods and Administration, New York: D. Appleton and Co.

Dewey, Davis Rich (1910). State Banking Before the Civil War, Washington: National Monetary Commission.

Diamond, Douglas W. (1984). "Financial intermediation and Delegated Monitoring," Review of Economic Studies 51 (July): 393-414.

Duncombe, Charles (1841). Duncombe's Free Banking, Cleveland: Sanford \& Co. Gorton, Gary (1985). "Bank Suspension of Convertibility," Journal of Monetary Economics, 15 : 177-193. (1989a). "Free Banking, Wildcat Banking and the Market for Bank Notes," Finance Department, The Wharton School, University of Pennsylvania, Working Paper. (1989b). "Self-Regulating Banking Coalitions," Finance Department, The Wharton School, University of Pennsylvania, Working Paper. 
Gorton, Gary and Donald J. Mullineaux (1987). "The Joint Production of Confidence,

Endogenous Regulation and Nineteenth Century Commercial-Bank Clearing Housing,"

Joumal of Money, Credit and Banking 19 (November) 1987: 457-468.

Hunt's Merchants' Magazine, various issues.

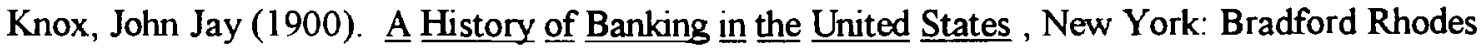
$\&$ Co.

Lake, Wilfred S. (1947). "The End of the Suffolk System," Journal of Economic History 7: $182-$ 207.

Miller, Merton H. and Daniel Orr (1968). "The Demand for Money by Firms: Extensions of Analytic Results," Journal of Finance 23: 735-759.

Mullineaux, Donald J. (1987). "Competitive Moneys and the Suffolk Bank System: A

Contractual Perspective," Southern Economic Joumal (April): 884-897.

Nicholas, Henry C. (1907). "Runs on Banks," Moody's Magazine (December): 23-26.

Redlich, Fritz (1968). The Molding of American Banking, Johnson Reprint Corp.

Root, L. Carroll (1901). “Twenty Years of Bank Currency Based on General Commercial Assets," Sound Currency, 8 (December), 209-232.

Schweikart, Larry (1988). “Jacksonian Ideology, Currency Control and Central Banking: A Reappraisal," The Historian (November): 78-102.

Tucker, George (1855). Progress of the United States in Population and Wealth in Fifty Years, New York: Press of Hunt's Merchants' Magazine.

United States Bureau of the Census (1850). Compendium of the Census of $\underline{1850}$

White, Eugene N. (1983). The Regulation and Reform of the American Banking System, 1900-

1929, Princeton: Princeton University Press.

White, Lawrence H. (1984). Free Banking in Britain. 1800-1845: Theory Experience and Debate, Cambridge: Cambridge University Press.

Whitney, D.R. (1878). The Suffolk Bank, Cambridge, Mass.: The Riverside Press. 
Table I

Aggregate Reserve Assets of Northeastern U.S. Banks, by Location, 1850

$\begin{array}{llll}\text { Location } & \text { Specie } & \text { Specie Funds } & \begin{array}{l}\text { Notes of } \\ \text { Other Banks }\end{array}\end{array} \quad \begin{aligned} & \text { Deposits in } \\ & \text { Other Banks }\end{aligned}$

NEW ENGLAND

\begin{tabular}{|c|c|c|c|c|}
\hline Connecticut & 575,656 & 58,337 & 196,268 & $1,470,853$ \\
\hline Maine & 402,231 & & 179,093 & 708,894 \\
\hline \multicolumn{5}{|l|}{ Massachusetts } \\
\hline Boston & $2,104,741$ & & $3,346,819$ & $2,103,708$ \\
\hline Rest of MA & 645,176 & & 390,332 & $2,369,242$ \\
\hline New Hampshire & 149,572 & & 109,818 & 432,782 \\
\hline \multicolumn{5}{|l|}{ Rhode Island } \\
\hline Providence & 181,454 & & 339,286 & 213,633 \\
\hline Rest of RI & 109,841 & & 104,159 & 271,285 \\
\hline Vermont & 120,798 & & 151,049 & 648,421 \\
\hline Total Suffolk System & $4,289,469$ & 58,337 & $4,816,824$ & $8,218,818$ \\
\hline \multicolumn{5}{|l|}{ MIDDLE ATLANTIC } \\
\hline Delaware & 147,612 & 17,727 & 72,992 & 218,341 \\
\hline \multicolumn{5}{|l|}{ Maryland } \\
\hline Baltimore & $2,119,860$ & & 634,475 & 548,367 \\
\hline Rest of MD & 348,375 & 59,789 & 156,030 & 520,220 \\
\hline New Jersey & 620,689 & & 383,008 & $1,100,162$ \\
\hline \multicolumn{5}{|l|}{ New York } \\
\hline New York City & $7,169,016$ & $7,075,468$ & 707,274 & $4,067,528$ \\
\hline Rest of NY & 897,297 & 926,171 & $1,906,236$ & $6,763,162$ \\
\hline \multicolumn{5}{|l|}{ Pennsylvania } \\
\hline Philadelphia & $2,009,702$ & $2,054,229$ & $1,878,022$ & $1,246,715$ \\
\hline Rest of PA & $1,819,052$ & 261,154 & 924,096 & $1,776,886$ \\
\hline
\end{tabular}

Source: State banking data for balance sheets at the end of 1850 were published in U.S. House of Representatives Executive Document No. 122, 32nd Congress, 1st Session. 
Table II

Aggregate Capital and Bank Liabilities of Northeastem U.S. Banks, by Location, 1850

\begin{tabular}{|c|c|c|c|c|}
\hline Location & Capital & $\begin{array}{l}\text { Notes in } \\
\text { Circulation }\end{array}$ & $\begin{array}{l}\text { Individual } \\
\text { Deposits }\end{array}$ & $\begin{array}{l}\text { Deposits Du } \\
\text { Other Banks }\end{array}$ \\
\hline \multicolumn{5}{|l|}{ NEW ENGLAND } \\
\hline Connecticut & $8,928,264$ & $4,511,570$ & $1,831,291$ & 378,403 \\
\hline Maine & $3,098,000$ & $2,212,727$ & $1,119,252$ & 54,983 \\
\hline \multicolumn{5}{|l|}{ Massachusetts } \\
\hline Boston & $19,577,495$ & $5,971,371$ & $7,289,308$ & $4,494,818$ \\
\hline Rest of MA & $15,052,516$ & $9,729,564$ & $3,332,424$ & 225,997 \\
\hline New Hampshire & $2,203,950$ & $1,751,096$ & 453,672 & 0 \\
\hline \multicolumn{5}{|l|}{ Rhode Island } \\
\hline Providence & $8,217,950$ & $1,346,692$ & $1,013,702$ & 553,412 \\
\hline Rest of RI & $3,079,603$ & $1,178,857$ & 395,047 & 34,884 \\
\hline Vermont & $1,826,975$ & $2,322,962$ & 330,195 & 21,448 \\
\hline Total Suffolk System & $61,984,753$ & $29,024,839$ & $15,764,891$ & $5,763,945$ \\
\hline \multicolumn{5}{|l|}{ MIDDLE ATLANTIC } \\
\hline Delaware & 940,000 & 651,121 & 290,556 & 110,535 \\
\hline \multicolumn{5}{|l|}{ Maryland } \\
\hline Baltimore & $6,802,632$ & $2,062,525$ & $3,862,269$ & $1,642,998$ \\
\hline Rest of MD & $1,902,079$ & $1,028,883$ & $1,321,340$ & 89,815 \\
\hline New Jersey & $3,565,288$ & $2,548,351$ & $1,894,237$ & 298,560 \\
\hline \multicolumn{5}{|l|}{ New York } \\
\hline New York City & $25,439,990$ & $6,013,349$ & $28,928,488$ & $12,848,838$ \\
\hline Rest of NY & $20,101,718$ & $18,152,631$ & $19,310,038$ & $5,873,422$ \\
\hline \multicolumn{5}{|l|}{ Pennsylvania } \\
\hline Philadelphia & $9,915,256$ & $4,130,609$ & $11,527,367$ & $3,375,185$ \\
\hline Rest of PA & $7,266,918$ & $7,274,846$ & $4,173,783$ & 590,688 \\
\hline
\end{tabular}

Source: State banking data for balance shets at the end of 1850 were published in U.S. House of Representatives Executive Document No. 122, 32nd Congress, 1 st Session. 
Table III

Notes and Capital of Northeastern U.S. Banks, Per Capita, by Location, 1850

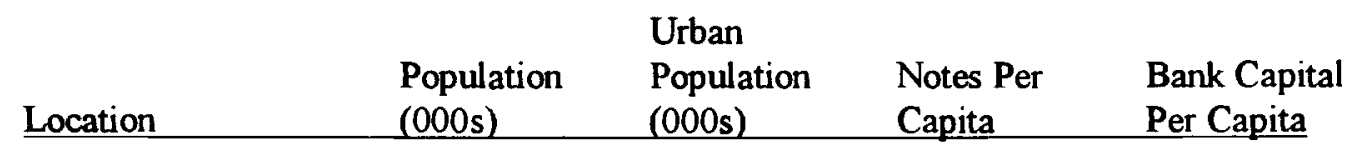

\section{A. State Comparisons}

NEW ENGLAND

$\begin{array}{lrrrr}\text { Connecticut } & 371 & 59 & 12.16 & 24.07 \\ \text { Maine } & 583 & 79 & 3.80 & 5.31 \\ \text { Massachusetts } & 995 & 504 & 15.81 & 34.80 \\ \text { New Hampshire } & 318 & 54 & 5.51 & 6.93 \\ \text { Rhode Island } & 148 & 82 & 17.06 & 76.33 \\ \text { Vermont } & 314 & 6 & 7.40 & 5.82 \\ & & & & \\ \text { MIDDLE ATLANTIC } & & 14 & 7.08 & 10.22 \\ \text { Delaware } & 92 & 188 & 5.30 & 14.93 \\ \text { Maryland* } & 583 & 86 & 5.20 & 7.28 \\ \text { New Jersey } & 490 & 873 & 7.80 & 14.71 \\ \text { New York } & 3,097 & 545 & 4.93 & 7.43 \\ \text { Pennsylvania } & 2,312 & & & \end{array}$

B. Inside and Outside Financial Centers

\section{NEW ENGLAND}

\begin{tabular}{lrrrr}
\hline Boston & 137 & 137 & 43.59 & 142.90 \\
Rest of MA & 858 & 367 & 11.34 & 17.54 \\
& & & & \\
Providence & 42 & 42 & 32.06 & 195.67 \\
Rest of RI & 106 & 40 & 11.12 & 29.05 \\
& & & & \\
MIDDLE ATLANTIC & & 169 & 12.20 & 40.25 \\
Baltimore & 169 & 19 & 2.49 & 4.59 \\
Rest of MD & 414 & 516 & 11.65 & 48.60 \\
& & 357 & 7.03 & 7.93 \\
New York City & 516 & & & \\
Rest of NY & 2,581 & 340 & 12.15 & 29.16 \\
& & 205 & 3.69 & 3.69 \\
Philadelphia & 340 & & & \\
Rest of PA & 1,972 & & &
\end{tabular}

* The white population of Maryland was 418,000 . Using that figure, notes per capita are 7.39.

Sources: Population data are from U.S. Bureau of the Census (1850). Urban locations are those with more than 2,500 inhabitants. Banking data are from Tables I and II. 
Table IV

Notes and Capital of Northeastem U.S. Banks Relative to Income, by Location, 1850

\begin{tabular}{lllll} 
& Notes Per & Notes Per & Bank Capital & Bank Capital \\
& Total & Non-Agricul- & Per Total & Per Non-Agri- \\
Location & Income & tural Income & Income & cultural Income \\
\hline
\end{tabular}

\section{NEW ENGLAND}

\begin{tabular}{lrrrr}
\hline Connecticut & 11.87 & 19.62 & 23.50 & 38.82 \\
Maine & 6.51 & 12.29 & 9.11 & 17.21 \\
Massachusetts & 14.81 & 18.26 & 32.67 & 40.27 \\
New Hampshire & 7.96 & 17.51 & 10.02 & 22.04 \\
Rhode Island & 14.86 & 18.04 & 66.46 & 80.70 \\
Vermont & 10.56 & 33.19 & 8.30 & 26.10 \\
& & & & \\
MIDDLE ATLANTIC & & & & \\
Delaware & 9.30 & 21.70 & 13.43 & 31.33 \\
Maryland* & 8.14 & 17.17 & 22.91 & 48.36 \\
New Jersey & 5.66 & 10.19 & 7.92 & 14.26 \\
New York & 9.29 & 16.67 & 17.52 & 31.41 \\
Pennsylvania & 6.30 & 11.88 & 9.49 & 17.90
\end{tabular}

Sources: Income data are from U.S. Bureau of the Census (1850). Banking data are from Tables I and II. 
Table V

Notes and Capital of Northeastem U.S. Banks Relative to Tangible Wealth, by Location, 1850

\begin{tabular}{llll} 
& Tangible & Notes Per & Bank Capital \\
& Wealth & $\$ 1,000$ Tangible & Per $\$ 1,000$ \\
Location & (\$millions) & Wealth & Tangible Wealth \\
\hline
\end{tabular}

\section{NEW ENGLAND}

$\begin{array}{lrrr}\text { Connecticut } & 155.7 & 28.9 & 57.2 \\ \text { Maine } & 122.8 & 18.0 & 25.2 \\ \text { Massachusetts } & 573.3 & 27.5 & 60.4 \\ \text { New Hampshire } & 103.7 & 16.9 & 21.3 \\ \text { Rhode Island } & 80.5 & 31.2 & 140.4 \\ \text { Vermont } & 92.2 & 25.2 & 19.8\end{array}$

\section{MIDDLE ATLANTIC}

$\begin{array}{lrrr}\text { Delaware } & 18.9 & 34.3 & 49.7 \\ \text { Maryland } & 219.2 & 14.1 & 39.7 \\ \text { New Jersey } & 153.2 & 16.6 & 23.3 \\ \text { New York } & 1,080.3 & 22.4 & 42.2 \\ \text { Pennsylvania } & 729.1 & 15.6 & 23.6\end{array}$

Sources: Tangible wealth is defined as the market value of the sum of real estate and personal estate. Data are based on U.S. Bureau of the Census (1850), and are taken from Tucker (1855), Appendix to Chapter XIV, p. 67. Banking data are from Tables I and II. 


\section{Table VI}

Specie Holdings Relative to Liabilities of the Public, and Relative to Reserves, by Location, 1850

Location

\section{A. State Comparisons}

\section{NEW ENGLAND}

Connecticut

Maine

Massachusetts

New Hampshire

Rhode Island

Vermont

Total Suffolk System

MIDDLE ATLANTIC

Delaware

New Jersey

New York

Pennsylvania
0.14

0.25

0.13

0.09

0.12

0.09

0.07

0.06

0.05

0.08

0.10

0.12
0.25

0.31

0.25

0.22

0.24

0.13

0.25

0.32

0.56

0.30

0.27

0.32

B. Inside and Outside Financial Centers

\section{NEW ENGLAND}

Boston

Rest of MA

Providence

Rest of RI

MIDDLE ATLANTIC

Baltimore

0.28

0.14

0.15

New York City

Rest of NY

0.02

0.11

0.15

Philadelphia

Rest of PA
0.28

0.19

0.25

0.23

0.64

0.32

0.38

0.09

0.28

0.38

Source: Banking data are from Tables I and II. 
Table VII

Net Public Liabilities, Relative to Specie Holdings and Capital, by Location, 1850

Location

Notes + Deposits of Individuals/Specie

Notes+Deposits/Capital

\section{A. State Comparisons}

NEW ENGLAND

Connecticut

10.68

0.69

Maine

7.08

1.01

Massachusetts

8.22

0.65

New Hampshire

14.01

0.95

Rhode Island

11.98

0.31

Vermont

20.71

1.37

Total Suffolk System

10.77

0.86

MIDDLE ATLANTIC

Delaware

5.88

0.92

Maryland

3.03

0.86

New Jersey

6.54

1.14

New York

7.41

1.31

Pennsylvania

6.35

1.41

B. Inside and Outside Financial Centers

NEW ENGLAND

Boston

0.51

Rest of MA

19.64

0.84

Providence

11.14

0.25

Rest of RI

13.37

0.48

MIDDLE ATLANTIC

Baltimore

0.78

Rest of MD

6.30

1.15

New York City

4.78

1.36

Rest of NY

32.89

1.44

Philadelphia

6.86

1.39

Rest of PA

5.79

1.45

Source: Banking data are from Tables I and II. 
Table VIII

Sigma of Non-Reserve Asset Retums for Boston and New York City Banks, 1851 and 1853*

\title{
Sigma of Stock Returns
}

\author{
Boston (1851) New York City (1853)
}

$\begin{array}{ll}\text { Mean } & 0.0235 \\ \text { Median } & 0.0235 \\ \text { Standard Deviation } & 0.0044 \\ \text { Number of Observations } & 29\end{array}$

T-Statistic for Difference in Means

\section{Sigma of Non-Reserve Asset Retums}

Mean

Standard Deviation

Number of Observations

T-Statistic for Difference in Means
0.0149

0.0137

0.0031

29

0.0324

0.0354

0.0090

7
0.0566

0.0563

0.0160

7

* Sigma is defined as the annualized standard deviation of returns to non-reserve assets. Nonreserve asset sigma is inferred from the standard deviation of monthly stock retums, as described in the text. Monthly stock returns are measured for the calendar years 1851 and 1853, respectively.

Sources: End-of-month stock prices, dividends, dividend payments dates, and numbers of shares of stock are used to derive monthly stock returns. Stock returns and balance sheet ratios are used to derive non-reserve asset retums as described in the text. Data on these variables are published in Hunt's Merchants' Magazine , 1852 , v. 26, p. $610 ; 1853$, v. 27, p. 223; 1854, v. 30, pp. 348-350; and in Shipping and Commercial List, various issues. Balance sheet data on individual Boston banks for the end of 1850 are published in U.S. House of Representatives Executive Document No. 122,32 nd Congress, 1st session. Balance shet data on individual New York City banks for the end of 1853 are published in U.S. House of Representatives Executive Document No. 102, 33rd Congress, 1st session 
Table IX

Semiannual Dividend Payout Rates as a Percentage of Bank Capital*

Boston Other MA NYC Baltmr. Phila. Provid. Other RI Maine

\begin{tabular}{|c|c|c|c|c|c|c|c|}
\hline $1831(2)$ & 2.8 & 3.1 & & & & & \\
\hline $1833(2)$ & 3.0 & 3.2 & & & & & \\
\hline $1835(1)$ & 3.0 & 2.9 & & & & & \\
\hline $1839(2)$ & 2.9 & 3.1 & & & & & \\
\hline $1845(1+2)$ & 3.2 & & 3.1 & & & & \\
\hline $1846(1+2)$ & 3.3 & & 3.5 & & & & \\
\hline $1847(1)$ & 3.4 & 3.3 & 3.8 & 3.3 & 4.1 & & \\
\hline $1847(1+2)$ & 3.5 & & 3.6 & & & & \\
\hline $1848(1)$ & 3.7 & & 3.9 & & & & \\
\hline $1848(1+2)$ & 3.8 & & 4.1 & & & & \\
\hline $1849(1)$ & 3.8 & 3.7 & 4.2 & & & & \\
\hline $1849(1+2)$ & 3.8 & & 4.1 & & & & \\
\hline $1850(1)$ & 3.9 & 4.1 & 4.9 & & 4.8 & & \\
\hline $1850(1+2)$ & 3.8 & & 4.4 & & & & \\
\hline $1851(1+2)$ & 3.8 & & 5.0 & & 4.8 & & \\
\hline $1851(2)$ & 3.6 & & & & & 3.7 & 3.7 \\
\hline $1852(1)$ & 3.7 & & & & & & \\
\hline $1852(2)$ & & & & & 5.2 & & \\
\hline $1852(1+2)$ & 3.8 & 3.7 & 4.5 & & & & \\
\hline $1853(1)$ & 3.9 & & 4.2 & & & & \\
\hline $1853(2)$ & 4.0 & & 4.2 & & & & \\
\hline $1854(1)$ & 4.1 & 4.0 & 4.0 & & & & \\
\hline $1854(2)$ & 4.0 & 4.3 & 4.4 & & & & \\
\hline $1855(1)$ & 4.0 & & 4.0 & & & & \\
\hline $1855(2)$ & 3.4 & 4.1 & 4.2 & & & & \\
\hline $1856(1)$ & 3.9 & & 4.2 & & & & \\
\hline $1856(2)$ & 3.7 & 4.2 & & & & & \\
\hline $1857(1)$ & 3.9 & 4.0 & & & 4.7 & & \\
\hline
\end{tabular}

* Semiannual dividend payout rates are either given for each half of the year separately, as indicated by either (1) or (2), or are given as the semiannual average of both dividend payments, as indicated by $(1+2)$.

Source: Hunt's Merchants' Magazine, various issues. 
Table X

Market-To-Book Value Ratio of Bank Equity, Boston and New York City Banks, 1851 and 1853*

Market-To-Book Value Ratio

Boston (1851) New York City (1853)

Mean

0.948

0.950

Median

0.942

0.029

0.946

Standard Deviation

29

0.076

Number of Observations

33

T-Statistic for Difference in Means

0.13

Sources: End-of-month stock prices for month closest to balance sheet date are used to measure market value of equity. Book value of equity equals capital plus surplus. Data on stock prices for Boston banks are December 1850 data from Hunt's Merchants' Magazine , 1852, v. 26, p. 610. Data on stock prices for New York City banks are the data closest to the December 3 balance sheet reporting date available from Shipping and Commercial List, various issues. Balance sheet data on individual Boston banks for September 1850 are published in U.S. House of Representatives Executive Document No. 122, 32nd Congress, 1st session. Balance shet data on individual New York City banks for December 1853 are published in U.S. House of Representatives Executive Document No. 102, 33rd Congress, 1st session. 
Figure 1

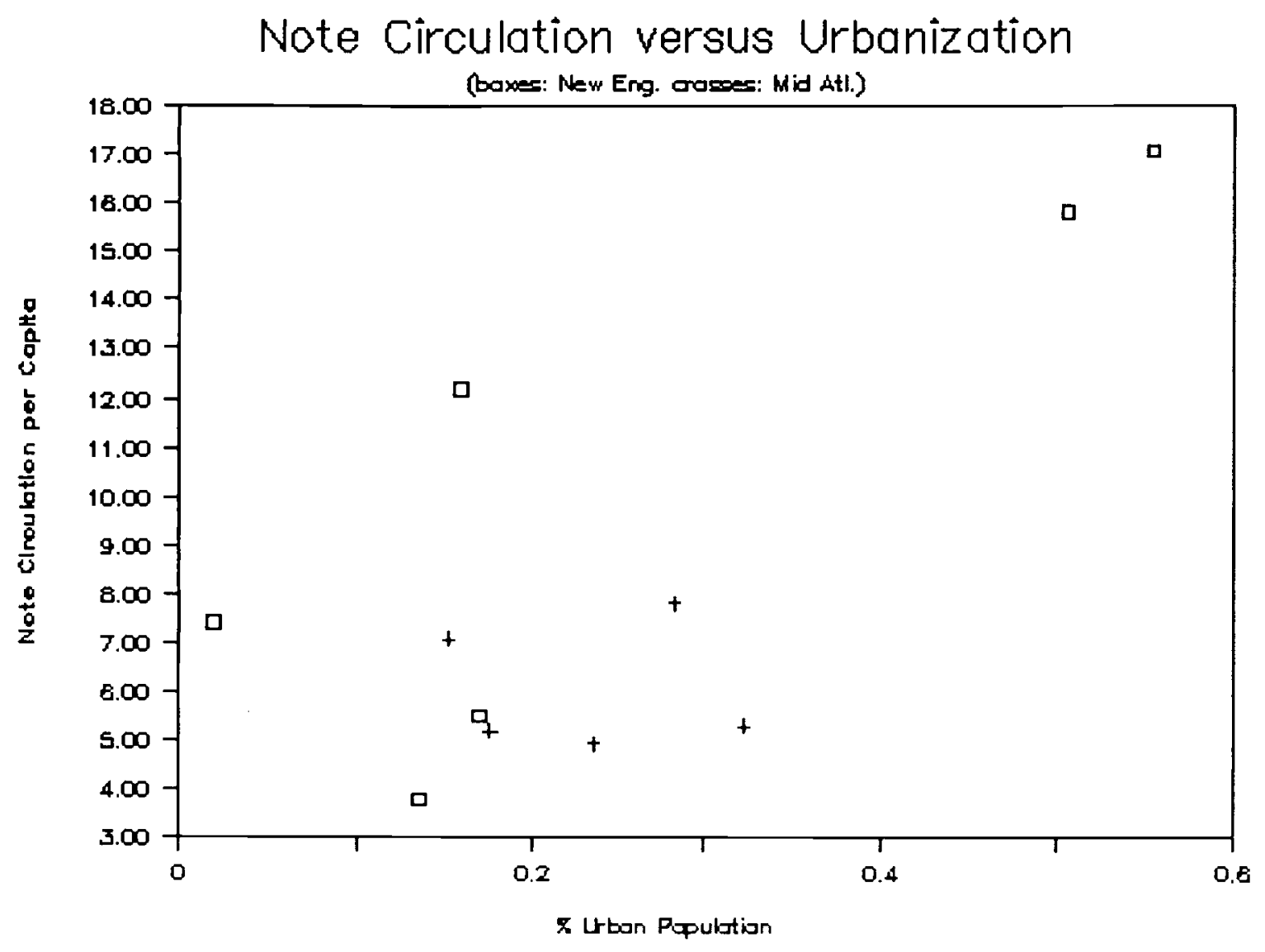

Figure 2

Note Circulation versus Urbanization

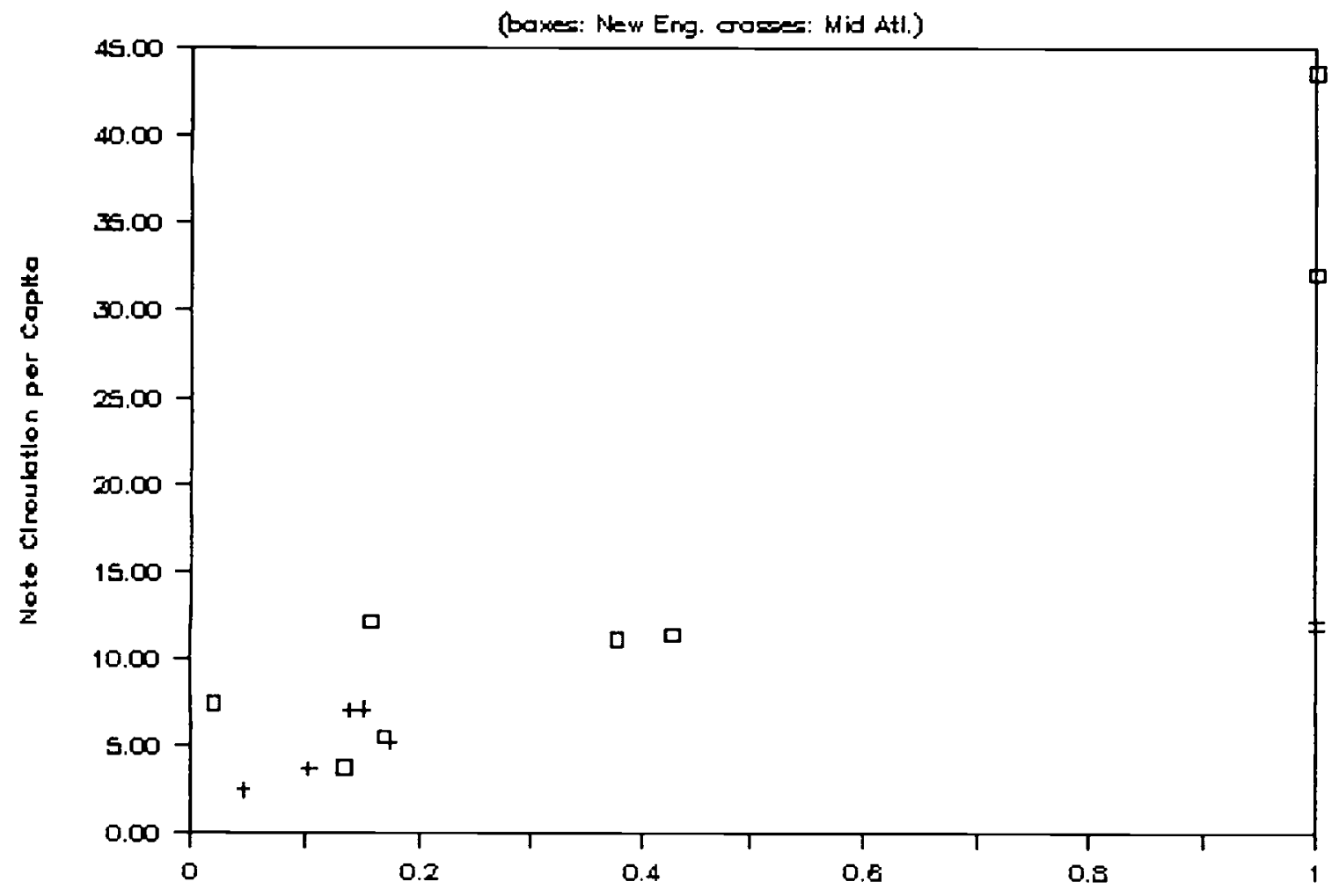


Figure 3

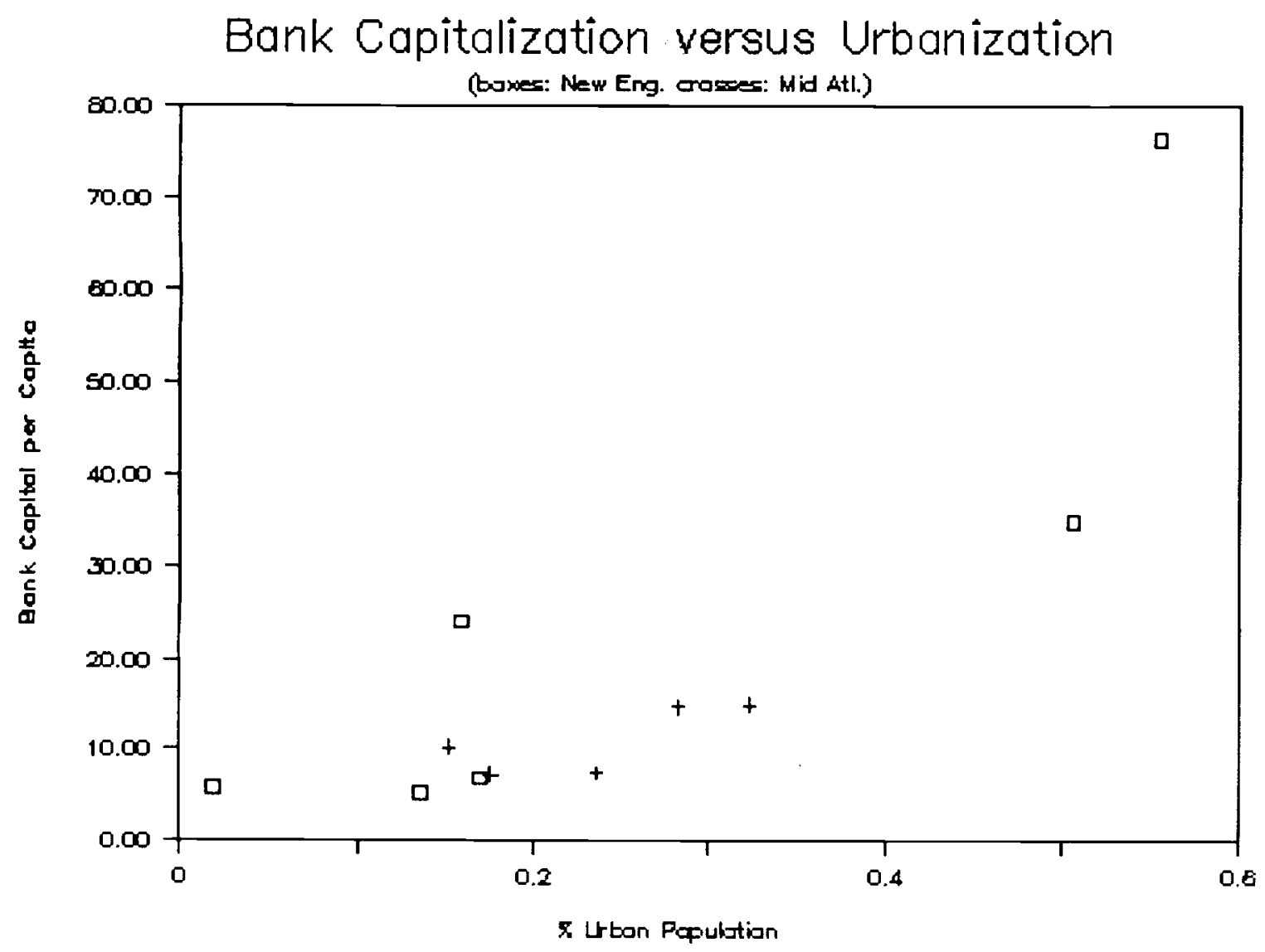

Figure 4

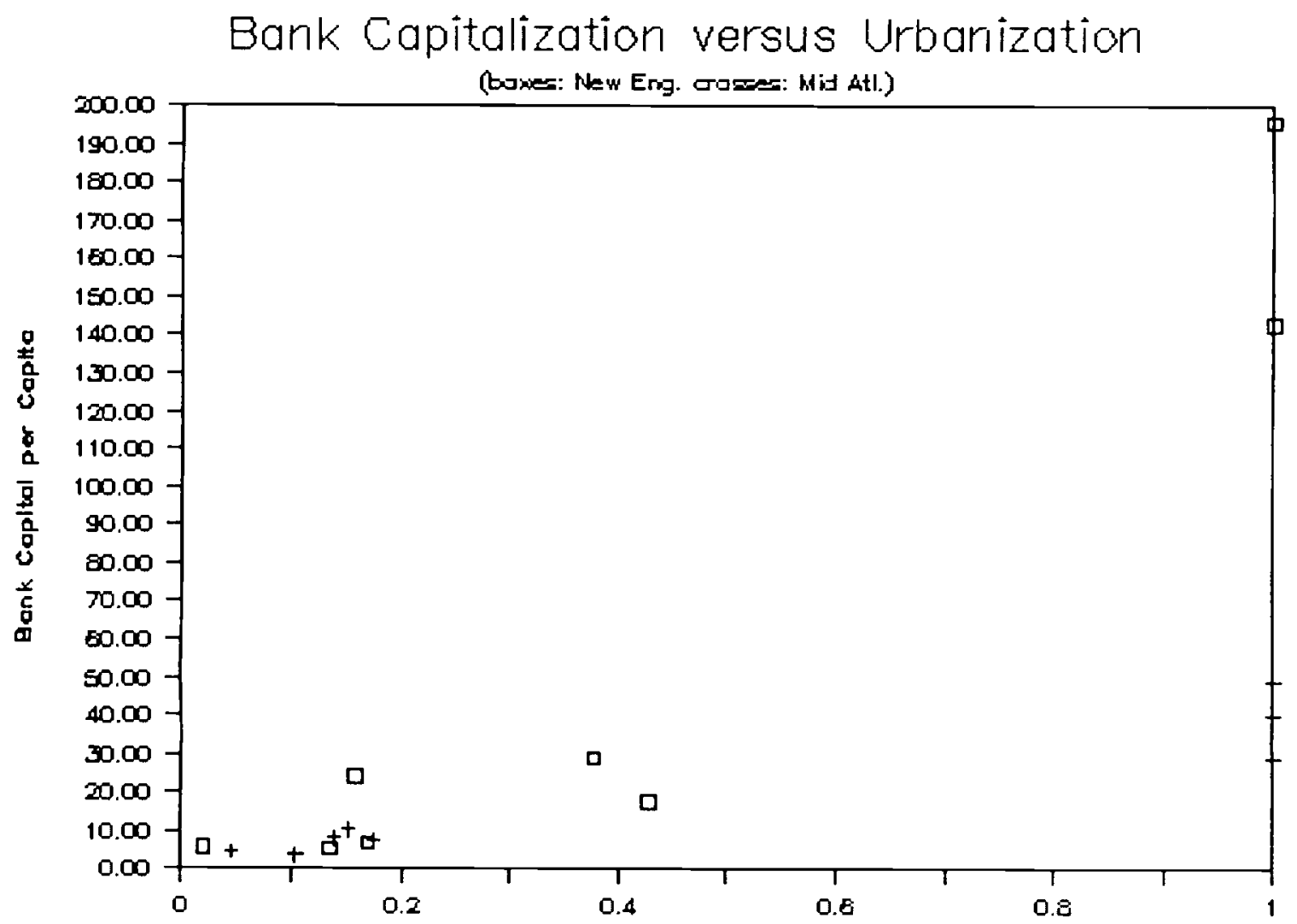

